This item was submitted to Loughborough's Research Repository by the author.

Items in Figshare are protected by copyright, with all rights reserved, unless otherwise indicated.

\title{
Pastoral idylls and lawless rebels: sexual politics in Books 5 and 6 of Spenser's Faerie Queene
}

PLEASE CITE THE PUBLISHED VERSION

PUBLISHER

Arkansas State University and (C) South-Central Renaissance Conference

VERSION

AM (Accepted Manuscript)

LICENCE

CC BY-NC-ND 4.0

\section{REPOSITORY RECORD}

Fitzpatrick, Joan. 2019. "Pastoral Idylls and Lawless Rebels: Sexual Politics in Books 5 and 6 of Spenser's Faerie Queene”. figshare. https://hdl.handle.net/2134/6248. 
This item was submitted to Loughborough's Institutional Repository (https://dspace.lboro.ac.uk/) by the author and is made available under the following Creative Commons Licence conditions.

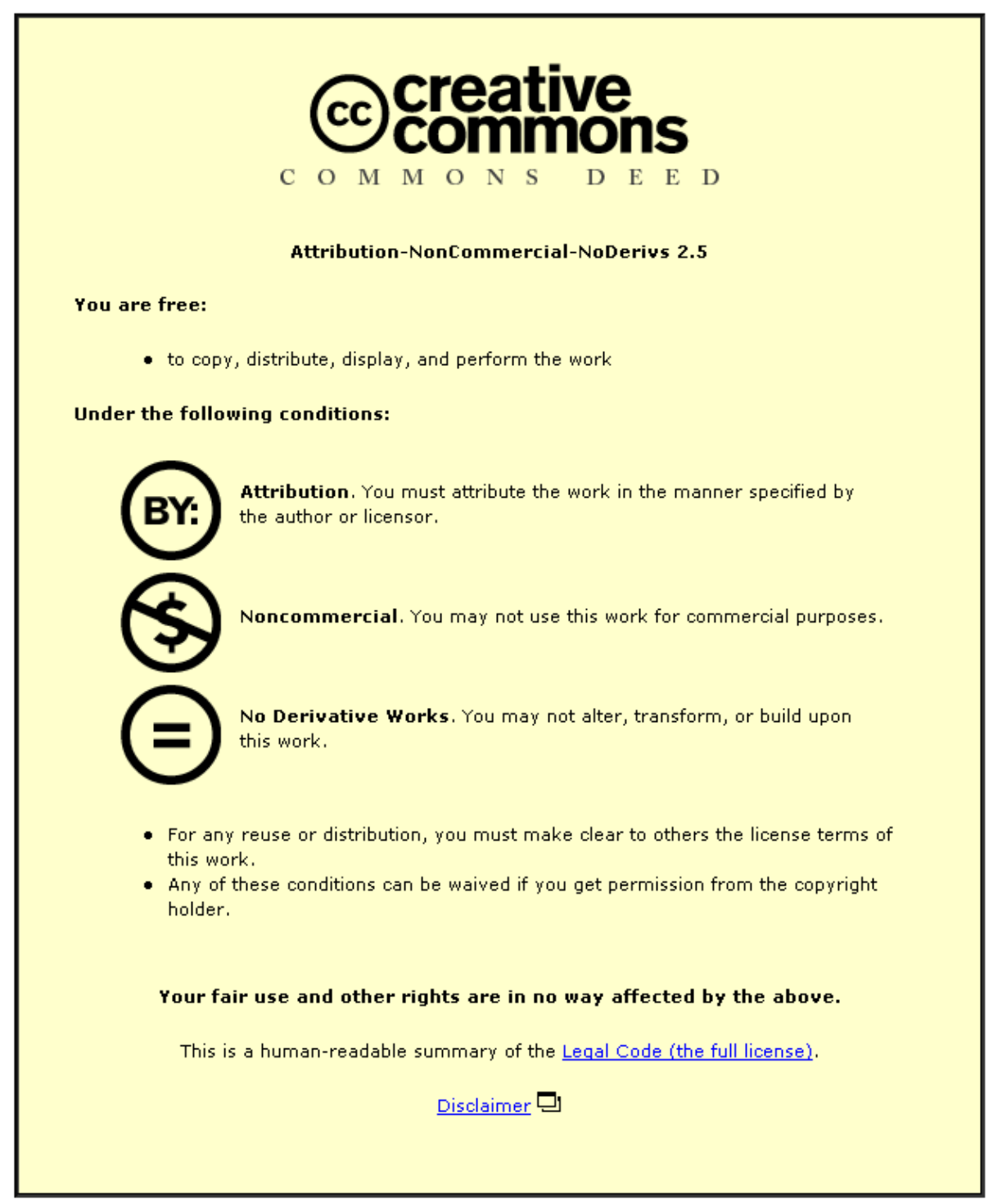

For the full text of this licence, please go to: http://creativecommons.org/licenses/by-nc-nd/2.5/ 


\section{Pastoral Idylls and Lawless Rebels: Sexual Politics in Books 5 and 6 of Spenser's Faerie Queene}

There have been numerous publications recently that focus on Spenser and Ireland and there have also been some illuminating studies of gender in The Faerie Queene. ${ }^{1}$ Sheila Cavanagh's Wanton Eyes and Chaste Desires: Female Sexuality in The Faerie Queene, published in 1994, is the first feminist re-reading of the entire text. Yet Cavanagh does not mention Ireland in her monograph which is indicative of a tendency to divide studies of Ireland and gender in critical readings of Spenser's work. ${ }^{2}$ One significant exception to this trend is Clare Carroll's "The Construction of Gender and the Cultural and Political Other in The Faerie Queene 5 and A View of the Present State of Ireland: the Critics, the Context, and the Case of Radigund" but even here the study concentrates only on the Irish dimension of the Radigund episode.

In The Faerie Queene rebellion is expounded in sexual terms and a nationalistic agenda appears evident in the fusion of the sexual and the territorial. The political issues of governance and control of a territory are presented via sexual dynamics whereby a woman's body is used as a symbol for the process of colonization and sexual dominance. The episodes featuring Pastorella (6.9-12) and Serena (6.8.3551) are typical of the tension that exists within Spenser's idealization and demonization of the pastoral existence. As more disturbing examples of discourtesy, images of aggression and sexual degradation are central to Spenser's depictions of debased, as opposed to idealized and courteous, pastoral life. Since critics concur that there are Irish dimensions to the uncivilized mobs who threaten Pastorella and Serena then we might ask what role these female victims of mob violence play in the allegory. In both episodes Spenser uses beauty as an important signifier in his conception of English nationalism and the position of the political and sexual Other. ${ }^{3}$ This paper explores the possibility that these episodes betray an anxiety about New English Protestants as victims of the Irish Catholic Other.

In the case of Pastorella, beauty is used as a metaphor for inherent nobility which implies civility, goodness and, most importantly, English Protestant superiority. This suggests that Pastorella is an ideal, a symbol of the New English colonialist in Ireland who, it is hoped, will remain untouched by the influence of the people amongst whom s/he lives. ${ }^{4}$ Serena falls asleep in a wood and is sexually assaulted and nearly eaten by the Saluage Nation, which similarly suggests New English fear of Native Irish violence expressed through metaphors of sexual penetration and consumption.

Innocent Pastorella is abducted by the Brigants but Serena is attacked by the Saluage Nation because she has ventured into their territory, a circumstance that makes the episode somewhat problematic because it may indicate a degree of complicity on her part. The only other episode in the poem where a woman is molested by a group of savages (as opposed to an individual savage man) occurs in the Flourdelis episode in Book 5. ${ }^{5}$ The allegory here is transparent: she represents France as a lady who was once loyal to her Protestant champion but has been unfaithful. Her collusion with the enemy is more overt than Serena's and, although virtually ignored by critics (she has no entry in the usually thorough Spenser 
encyclopedia), the episode deserves analysis in the context of those featuring Pastorella and Serena.

I hope to show that the tension evident in Spenser's conflicting representations of agrarian existence reveals anxieties about Catholic (particularly Irish) resistance and betrays concerns about political control in the colonial project. These anxieties are betrayed via the concept of violent sexual relations and the threat of miscegenation. Catholic rebellion, blame, punishment and sexual degradation or the threat of these is central to the Pastorella, Serena, and Flourdelis episodes. A useful parallel text that may illuminate these aspects of The Faerie Queene is A View of the Present $\underline{\text { State of Ireland }}^{6}$

\section{Pastorella and the Brigants}

Pastorella's name identifies her with the pastoral environment she inhabits. Her foster father, Meliboe, praises the pastoral existence, emphasizing its freedoms, selfsufficiency and the contentment it brings. It is a peaceful existence and its inhabitants are without pride or ambition (6.9.20-25). Calidore admires its freedom: "How much (sayd he) more happie is the state, / In which ye father here doe dwell at ease, / Leading a life so free and fortunate" (6.9.19.1-3). ${ }^{7}$ There is, however, evidence of an ambivalence towards rural life throughout The Faerie Queene. In the View the Irish landscape is described as both sinister and beautiful. On the one hand Irenius expresses a fear of the Irish landscape and urges the clearing of woodland to make it safe for travellers "whiche vse often in suche perillous places to be Robbed and sometimes murdered" (Spenser 1949, 224). On the other hand he comments on the physical beauty of Ireland and its economic usefulness, its potential:

And sure it is, it is a moste bewtifull and swete Countrie as anye is vnder heaven, seamed thoroughe out with manye goodlye rivers replenished with all sortes of fishe moste aboundantlye sprinckled with manye swete Ilandes and goodlye lakes like little Inlande seas, that will carye even shipps vppon theire waters, adorned with goodly woodes fitt for buildinge of howsses and shipps . . . besides the soile it self moste fertile fitt to yealde all kinde of fruite that shalbe committed thearevnto And Lastlye the heavens moste milde and temperate thoughe somwhat more moyste then the partes towardes the weste. (Spenser 1949, 62)

Similarly in the Pastorella episode the life of the shepherd is idyllic. Calidore comes across the shepherds:

Playing on pypes, and caroling apace, The whyles their beasts there in the budded broomes Beside them fed, and nipt the tender bloomes: For other worldly wealth they cared nought. (6.9.5.3-6)

Yet quite a different opinion is given of animal farming in the View where Irenius denounces as Scythian the practice of 'booleying' or transhumance which was an essential part of Irish pastoral reality (Spenser 1949, 97-99). As Nicholas Canny observes in The Elizabethan Conquest of Ireland the association of the nomadic Scythians with the Irish meant that "Here was evidence to satisfy Spenser that the 
Irish were indeed true barbarians, and this notion also became entrenched in the minds of sixteenth-century Englishmen" (Canny 1976, 127). Irenius objects that the booleys harbour "outlawes or loose people" (Spenser 1949, 98). He claims that, furthermore, the people in the booleys "growe theareby the more Barbarous and live more licentiouslye then they Could in townes", conspiring against the government and individuals. They steal, they murder, and think themselves to be exempt from the law. He concludes that such "fredome" is dangerous for "havinge once tasted fredome ... . [they] grudge and repine ever after to Come vnder rule againe" (Spenser 1949, 98). Why is it that the freedom celebrated by Calidore in the Pastorella episode is condemned as subversive in the View?

In his study of the Elizabethan pastoral form, Louis Montrose has noted that in the early modern period figurative pastoralism borrowed from literal pastoralism but rejected the harsh reality of its labour. The task of sheep herding was valorized and agrarian labour excluded from the vast majority of Elizabethan pastoral texts. This had its basis in the biblical moral hierarchy of Cain, a tiller of the ground, and Abel, a shepherd. Furthermore, the process was class based: literary pastoralism was dominated by aristocratic values and style even though most of its poets had humble origins. English literary pastoralism placed great emphasis on leisure in an attempt to mimic the leisure of the gentry who found manual labour unappealing. In pastoral literature the shepherd's toil is minimal and the manual labour required of other agrarian tasks is ignored. The main thrust of literary pastoralism was the imaginative creation of an elite society by a burgeoning middle class in an attempt to bring aristocratic values to the practice of sheep herding (Montrose 1983). In the Pastorella episode the pastoral idyll is invaded by the "lawlesse" Brigants who live on the periphery of the pastoral world. The Brigants are worse than the lowly ploughman because they live from theft. There is a tension between the figurative pastoralism of Spenser's imagination and the literal pastoralism of his real world, that is, his experiences in Ireland where Irish rebels proved to be a continual threat to the New English settlers. The attitude toward the landscape of Ireland in the View is ambivalent: the landscape is sometimes admired for its beauty and at other times feared for its dangers. Such ambivalence is not evident in the descriptions of the people who inhabit the landscape : attacks upon the Irish rural culture evident in their farming methods, particularly that of transhumance, are consistent. ${ }^{8}$

Although Pastorella is part of the pastoral community she is at the same time separate from it due to her origins. She has been fostered by Meliboe and his wife but she has not been fully assimilated and her inherent superiority is apparent. When Calidore first sees her she is seated "Vpon a litle hillocke . . . / Higher then all the rest" (6.9.8.1-2). As Sheila Cavanagh points out "Pastorella is raised both literally and figuratively above her pastoral companions" (Cavanagh 1994, 125). Her inherent nobility sets her apart from those around her and manifests itself in her extraordinary beauty:

And soothly sure she was full fayre of face, And perfectly well shapt in euery lim, Which she did more augment with modest grace, And comely carriage of her count'nance trim, That all the rest like lesser lamps did dim: Who her admiring as some heauenly wight, 
Did for their soueraine goddesse her esteeme,

And caroling her name both day and night,

The fayrest Pastorella her by name did hight. (6.9.9.1-9)

Despite growing up amongst humble people Pastorella's innate nobility remains intact. She rejects as her suitor the lowly shepherd Coridon, and others like him: "Yet neither she for him, nor other none / Did care a whit, ne any liking lend: / Though meane her lot, yet higher did her mind ascend" (6.9.10.7-9). This concept of inherent nature is central to the View. Irenius is strongly critical of the Old English who have forgotten their 'English nature' and become degenerate:

the Englishe that weare are now muche more Lawles and Licentious then the verie wilde Irishe, so that as muche Care as was then by them had to reforme the Irishe so muche and more muste now be vsed to reforme them so muche time dothe alter the manners of men. (Spenser 1949, 113)

The English have become debased "throughe licentious Conuersing with the Irishe or marryinge and fosteringe with them or lacke of mete nourture" (Spenser 1949, 117). In the View, Irenius claims that the Irish and the Scots have common ancestors, both being derived from the Scythians who arrived first in Ireland and later proceeded into Scotland (Spenser 1949, 83). ${ }^{9}$ It is relevant that Pastorella's biological mother Claribell consciously refused to allow herself to become degenerate by marrying a Scot:

Her name was Claribell, whose father hight The Lord of Many llands, farre renound For his great riches and his greater might. He through the wealth, wherein he did abound, This daughter thought in wedlocke to haue bound Vnto the Prince of Picteland bordering nere, But she whose sides before with secret wound Of loue to Bellamoure empierced were, By all meanes shund to match with any forrein fere. (6.12.4.1-9)

Anne Fogarty rightly states that in the View Irenius puts forth "his blueprint for an idealized Ireland which, through carefully executed alterations, has been transformed into a perfect icon of imperial power" (Fogarty 1989, 88). The environment in which Pastorella has been brought up is a symbol of an idealized Ireland of Spenser's imagination, one containing the subjugated Irish. Pastorella typifies what is strongly desired by Irenius: unassimilated inherent nobility. She may therefore be a symbol of the New English colonialists who it is hoped will not allow themselves to become degenerate as did the settlers of the twelfth century who are chastised by Irenius.

Although their depiction is informed by the conventions of Greek romance, the Brigants who destroy the peaceful existence of this pastoral idyll show every sign of being Irish rebels:

A lawlesse people, Brigants hight of yore, That neuer vsde to liue by plough nor spade, 
But fed on spoile and booty, which they made Vpon their neighbours, which did nigh them border, $(6.10 .39 .3-6)^{10}$

The actions of the Brigants against the pastoral community are violent; they "spoyld their houses, and them selues did murder; / And droue away their flocks, with other much disorder" (6.10.39.8-9). Spenser would have been aware of pirates and warriors in the Greek romances of Heliodorus and Longus, ${ }^{11}$ but he was living (and writing The Faerie Queene) in an environment where raids upon a neighbours territory were a common occurrence; the Native Irish around him were available as ever-present models of brigandry. ${ }^{12}$ In The Image of Ireland John Derricke depicts a cattle raid on the Pale and his comments on the actions of the Irish rebels are remarkably similar to Spenser's description of the actions of the Brigants: the raiders are denounced as "a packe of prowling mates" who "spoyle, and burne, and beare away, as fitte occasions serue" and, when they are finished their destruction, they "returne backe to the wood, from whence they came" (Moody, Martin \& Byrne 1976, plate 2). ${ }^{13}$ Similarly in A Brief Note of Ireland, the description of the actions of the Irish rebels in the Munster rebellion led by Tyrone echoes the violent actions of the Brigants:

And going straight vppon the English as they dwelt disparsed before they could assemble themselues spoiled them all, there howses sacked and them selues forced to flie away for safetye, so many as they could catch they hewed and massacred miserablie the rest leaving all behinde them fledd with their wives and Children to such porte townes as were next them . . . (Spenser 1949, 238, lines 122-27)

Furthermore, the description of the Brigants as "Like a sort of hungry dogs" (6.11.17.1) is echoed in A Brief Note of Ireland in the plea that Elizabeth take severe action against Irish rebellion and so give succour to the New English Planters: "[we] haue nowe nothing left but to cry vnto you for tymelie aide before we be brought to vtter distruction and our wreched liues (which onelie now remaine vnto vs be made the pray of dogges and sauage wilde beastes . . .)" (Spenser 1949, 241, lines 21923). In the View Irenius repeatedly characterizes the Irish as lawless thieves, guilty of disorder and destruction.

Further evidence that the Brigants are Irish is the description of where they live:

Their dwelling in a little Island was,

Couered with shrubby woods, in which no way

Appeard for people in nor out to pas,

Nor any footing fynde for ouergrowen gras.

(6.10.41.6-9)

In many parts of Ireland woodland provided protection for the Irish rebel (Derricke's raiders "returne backe to the wood, from whence they came") and made an area dangerous or even inaccessible to the New English colonizer. This was particularly true of northern Ireland which had some of the most impenetrable areas of woodland and bogs. Eileen McCracken states that the features of the Irish landscape "had been a serious obstacle to the Tudor conquest and colonization of Ireland. The Irish had resisted the invaders from the shelter of the bogs and the woods whenever 
possible" (McCracken 1959, 287). R. A. Butlin agrees that the woods were literally sites of resistance for the Irish and hostile, unknown areas for the English colonialist: "Inland, there can have been very few roads, and journeys on horseback through the 'straits', passes, and fastnesses were fraught with dangers, both from the enemy and from the elements" (Butlin 1976, 162). The Irish landscape familiar to Spenser is similar to that of The Faerie Queene in many of its features. Arnold William's description of Spenser's fairyland as "rough and dangerous country, unprovided with signposts and road maps" (Williams 1967, 48) also accurately describes the early modern Irish interior. In sixteenth-century Ireland, as in the imaginative landscape of fairyland, the woodland harbours the savage Other who attempts to harm good knights and molest their ladies. Comments on the impassability of the Irish landscape, because of geographical impediments and danger, are common in English colonialist writings on Ireland. Thomas Gainsford (1618) says of Munster: "The grounds adiacent are very fertile . . . but more inward they are very barren and mountanous, full of boggs, wood, and other remote places, whose fastnes hath incited the people to ouer- great presumption" (Gainsford 1618, 145). Similarly in "A Booke of Questions and Answars Concerning the Warrs or Rebellions of the Kingdome of Ireland" ${ }^{14}$ the woodland is a refuge for the rebels of Leinster who are said to "hide themselues in the day tymes in the mountaines, and glenes, woods \& bogs of the prouince, and quarter themselues in the night or euening to go to seeke victualls of the peacable subiects. .. " (Morgan 1995, 98) In The Faerie Queene Spenser's Brigants "fed on spoile and booty, which they made / Vpon their neighbours, which did nigh them border" (6.10.39.5-6).

Humphrey Tonkin's remark that the attack of the Brigants "is not simply an attack on the shepherds' way of life, but a frontal assault on the idea of courtesy itself, as symbolized by Pastorella" (Tonkin 1972, 143-44) is even more significant if we understand that for Spenser courtesy was a secular code of behaviour informed by Christian values (Borris 1990, 194). As William Tayler points out, Book 6 "is a pastoral romance in the tradition of Daphnis and Chloe and Sidney's Arcadia" and a "moral allegory" that "offers a panoramic view of manners and morals, spanning the entire range from true courtesy to complete baseness" (Tayler 1964, 103). That the Brigants are antithetical to Christianity as well as courtesy is suggested by their diabolical hide-out: "vnderneath the ground" in "hollow caues" hidden by "thick shrubs" and consumed by "darknesse dred" (6.10.42.1-5), recalling the dark cave where Error, the enemy of Truth and Holiness, dwells in Book 1 (1.1.11-14). Tonkin notes that the episode is "a kind of infernal parody" (Tonkin 1972, 144) of the pastoral existence whereby the Brigants plunge the "inhabitants of a green and sunlit world, into the wintry darkness of their anti-society beneath the earth" (Tonkin 1972, 143). In the View, Irenius identifies ignorant Irish Catholics as non-Christian:

Therefore the faulte that I finde in religion is but one but the same vniuersall throughe all that Countrye, that is that they are all Papistes by theire profession but in the same so blindelye and brutishly enformed for the moste parte as that ye woulde rather thinke them Atheists or infidels but not one amongest a hundred knowethe anye grounde of religion anie article of his faithe but Can perhaps saie his pater noster or his Ave marye without anie knowledge or vnderstandinge what one worde theareof meanethe.(Spenser 1949, 136) 
Although the Brigants behave in a manner antithetical to the code of courtesy, they are not immune to its pleasures. When Pastorella is abducted by the Brigants her beauty triggers the desire of their Captain:

One day as he did all his prisoners vew, With lustfull eyes, beheld that louely guest, Faire Pastorella, whose sad mournefull hew Like the faire Morning clad in misty fog did shew. (6.11.3.6-9)

In the pastoral world even the barbarian conforms to the rules of romantic love: he woos her and she shows him some favour because she fears rape, but she is careful to keep her chastity intact. Her greatest fear is that she will be forced to accept penetration by her enemy which will render her unworthy of the noble Calidore's love. As a symbol of the supposedly morally superior nature of inherent nobility she much not allow herself to be penetrated by her social and cultural inferior. The reader's sympathy for Pastorella is elicited to underline the moral correctness of her position and what she embodies. The narrator repeatedly laments her predicament, while the Captaine who is attracted to her is characterized as lustful.

The fact that Pastorella and her people are to be sold as slaves betrays an anxiety about power, ownership, and hierarchial relationships in Ireland. Pastorella manages to gain control of a situation that threatens the chastity upon which her social value is predicated. Here, as so often in English colonialist writings, colonizer and colonized are positioned within in a paradigm of sexual relations. The land as a green-sick virgin ripe for penetration is evident in Raleigh's famous description (1596) of Guiana as "a countrey that hath yet her maidenhead" (Raleigh 1596, sig. N4v). Similarly in Luke Gernon's A Discourse of Ireland (1620), Ireland itself is conceptualized as a young woman suffering from greensickness:

This Nymph of Ireland, is at all poynts like a yong wenche that hath the greene sicknes for want of occupying. She is very fayre of visage, and hath a smooth skinn of tender grasse. . . . It is nowe since she was drawne out of the wombe of rebellion about sixteen yeares, by'rlady nineteen, and yet she wants a husband, she is not embraced, she is not hedged and diched, there is noo quicksett putt into her. (Falkiner 1904, 349-50) ${ }^{15}$

The word 'husband' serves a double function, signifying the cure of a 'husband' and suggesting the cognate word 'husbandry' meaning farming and careful management. What is unusual in the case of Pastorella is the emphasis on the colonizer as resilient virgin on guard against penetration by the colonized Irish, instead of the usual exhortation to the colonizer to penetrate fair Ireland. A similar situation is evident in Shakespeare's The Tempest in Caliban's desire to penetrate the virginal Miranda (1.2.347-353). What appears to be evident in the abduction of Pastorella is anxiety about miscegenation, particularly the coupling of a 'civilized' woman with a member of the indigenous people.

An historical example of such a coupling was the marriage in 1591 between Hugh O'Neill, the Earl of Tyrone, and Mabel Bagenal, daughter of the retired Queen's Marshal Sir Nicholas Bagenal and sister of the then current Queen's Marshal, Sir Henry Bagenal. This event is often ignored by Irish historians, presumably because it concerns the private life of O'Neill, but is the subject of the play Making History by 
the modern Irish dramatist Brian Friel. O'Neill is the central character and the action takes place before and after the battle of Kinsale in which he was defeated. The play also depicts domestic scenes between O'Neill and his new wife. It is made clear that neither O'Neill's comrades nor Mabel's family are happy with the marriage. Hugh O'Donnell, the Earl of Tyrconnell, is outraged when he hears about the match: "Hold on, Hugh--wait now--wait--wait. You can't marry into the Upstarts! And a sister of the Butcher Bagenal! Jesus, man--" (Friel 1989, 13). When Mabel's sister Mary comes to visit she brings with her some herb seeds and warns Mabel not to plant them too close together: "You'll end up with a seed that's neither one thing or the other" (Friel $1989,22)$. Later in their dialogue Mary is explicit about her feelings concerning the marriage:

Listen to yourself. You're becoming slippery like them! You're beginning to talk like them, to think like them! Hugh is a traitor, Mabel--to the Queen, to her Deputy, to everything you and I were brought up to believe in. Do you know what our people call him? The Northern Lucifer--the Great Devil-- Beelzebub! Hugh O'Neill is evil incarnate, Mabel! (Friel 1989, 25)

Mary speaks on behalf of the New English in Ireland, voicing the belief that the alien Irish way of thinking and speaking, the natives' 'slipperiness', was contagious. She puts great emphasis on loyalty to the queen, on tradition, culture, and most importantly the approval of one's own people. The evidence of The Faerie Queene suggests that Friel's work catches well the anxieties of leading political figures and their families in early modern Ireland, and especially the New English fear of miscegenation.

In "The Influence of Spenser's Irish Experiences on The Faerie Queene" M. M. Gray considers that the abduction of Pastorella "suggest[s] the possibility of some real incident of this kind as a source" and quotes from the report of an English captain attacked in his castle by Irish rebels. The captain expresses concern for the safety of the women present "I was troubled with certain of my friends in my castle upon the assault, by name my sister, my wife and four gentlewomen of the pale, who wished themselves in their graves" (qut. in Gray 1930, 421). The captain fears that the rebels will harm the women, that they will be abducted, raped, or murdered. As in Friel's play and The Faerie Queene the captain's fears reveal the way in which the threat of sexual penetration of a woman's body is imbued with anxieties about political instability, the transgression of boundaries, miscegenation, and the potential defeat of the colonial project.

Pastorella's virtue is demonstrated by reference to her economic worth. The Captaine in The Faerie Queene jealously guards Pastorella and will not allow the merchants to buy her:

To whom the Captaine in full angry wize Made answere, that the Mayd of whom they spake, Was his owne purchase and his onely prize, With which none had to doe, ne ought partake, But he himself, which did that conquest make; 
At this point the identification of Pastorella with a specific group becomes problematic because she represents here not only the new colonizer of Ireland but the colonized, that is, the economically desirable potential of the land itself. Anne Fogarty senses the same apparently contradictory allegorical signification in the View: "If, as Gottfried proposes, one of its possible derivations is 'Irena', the term used for Ireland in The Faerie Queene, then Irenius may be regarded as the voice of the conquered land itself, which raises a plea for its own subjugation" (Fogarty 1989, 89). ${ }^{16}$

Pastorella is economically attractive despite the sickness she brings on herself in order to avoid the sexual contact that is a consequence of male praise. When the merchants see her they are struck by her beauty:

The sight of whom, though now decayd and mard, And eke but hardly seene by candle-light, Yet like a Diamond of rich regard, In doubtfull shadow of the darkesome night, With starrie beames about her shining bright, These marchants fixed eyes did so amaze, That what through wonder, and what through delight, A while on her they greedily did gaze, And did her greatly like, and did her greatly praize. (6.11.13.1-9)

Pastorella's apparent sickness has not erased her beauty; despite her trials she is still a valuable commodity and a capital investment. This is especially true if we agree that, at certain points in the allegory, she represents the land of Ireland itself. Here the language of colonial excavation meets the language of the poetic blazon, which frequently analogized female body parts as precious materials; "the diamond of rich regard" fuses ideas about sexual possession and economic value. ${ }^{17}$ Rebellion and unrest in Ireland were often described by colonialist commentators as sickness. In the View Irenius refers to the rebellion of Thomas Fitzgarrett and the Muster rebellion against Edward IV as a "contagion" (Spenser 1949, 63, 117). Similarly in A Brief Note of Ireland Elizabeth is informed that because members of her government conspired against Tyrone and because of divisions in the government the current situation has been brought

to that dangerous condicion that nowe they stand in. ffor from this head through tolleracion and too much temporizing the euill is spred into all partes of the Realme and growne in to so vniuersall a contagion that nothing but a moste violent medecyne will serue to recouer yt. (Spenser 1949, 238, lines 102-06)

In Barnaby Rich's The Anothomy of Ireland (1615), which like the View takes the form of a dialogue, Antodonus, one of the speakers, laments that "the dysceases of Irelande are many \& the sycknes is growne to that contagyon, that it is allmost past cure" (Hinton 1940, 83). ${ }^{18}$ Similarly, Fynes Moryson (1617) uses the metaphor of infection for what he regards to be the ill effects of the Catholic Native Irish on the Old English, or "English Irish" as he calls them: 
Touching the English Irish. . . . It is wonderfull yet most true, that for some later ages they haue beene (some in high some in lesse measure,) infected with the barbarous Customes of the meere Irish and with the Roman Religion so as they grewe not only as aduerse to the Reformation of Ciuill policye and religion, as the meere Irish but euen combyned with them, and shewed such malice to the English nation, as if they were ashamed to haue any Community with it, of Country, bloud, religion, language apparrell, or any such generall bond of amity. (Moryson 1903, 201-02)

Moryson also draws a connection between the Irish diet and a supposed lack of cleanliness that leads to contamination:

Many of the English-Irish, haue by little and little been infected with the Irish filthinesse, and that in the very cities, excepting Dublyn, and some of the better sort in Waterford, where the English continually lodging in their houses, they more retaine the English diet. (Moryson 1617, sig. Sss2r)

\section{Serena and the Saluage Nation}

That the Saluage Nation who attack Serena conform to the construction of the Native Irish as savage Other has been recognised by Gray, Chang, and McNeir. Although Gray stresses the influence of Greek myth, he recognizes that the sacrifice of Serena and the abduction of Pastorella show "what the English felt about the Irish rebels" (Gray 1930, 420). Similarly, with reference to the View, Chang draws a parallel between the savages who abduct Pastorella and Serena and Spenser's perception of Irish outlaws (Chang 1955, 129-35). McNeir agrees with Chang that Spenser's principal inspiration for the Saluage Nation was his perception of the Irish outlaws as barbaric (McNeir 1969, 153n115). Although Walter Staton claims that the depiction of the Saluage Nation is indebted to Renaissance Italian pastorals, it could be argued that the ritualistic element of the Italian pastorals and the "diuelish ceremonies" of the Saluage Nation's Priest, also suggest the Catholic Mass (Staton 1966, 36-38). Even Williams, who denies that there is an Irish dimension to the Saluage Nation, concedes that "The identification has perhaps a little truth, however, notably that the Irish living at a lower social level than the English are not therefore more virtuous but less" (Williams 1967, 50). Williams is too literal in his reading of the allegory when he claims that "certainly not even Spenser imputed anthropophagy or human sacrifice to the Irish" (Williams 1967, 50). Spenser need not have believed or claimed that the Irish ate human flesh to have use the notion of cannibalism as an indication of general barbarism with perhaps a hint of the Roman Catholic belief in transubstantiation. In the View Irenius reports that the Irish, like the Scythians before them, indulge in blood rituals:

Allsoe the Scythyans vsed when they would binde anie solempe vowe of Combinacion to drinke a bowle of blodd togeather vowinge theareby to spende theire laste blodd in that quarrell, And even so do the wilde Scottes as ye maie reade in Buchannan and some of the Northern Irishe likewise. (Spenser 1949, 108)

It is significant that the taboo ritual is celebrated by the northern Irish, recognised in this period as the most obdurate in their enmity against the New English. Similarly in the View Irenius refers to a scene he has witnessed that endorses the representation of the Irish as savage: 
at the execucion of A notable Traitour at Limericke Called murrogh Obrien I sawe an olde woman which was his foster mother take vp his heade whilste he was quartered and sucked $\mathrm{vp}$ all the blodd rvnninge theareout Sayinge that the earthe was not worthie to drink it and thearewith allso steped her face, and breste and torne heare Cryinge and shrikinge out moste terrible. (Spenser 1949, 112)

The epithet 'saluage' is used throughout the View with reference to both Ireland and the Irish people and also occurs regularly in The Faerie Queene. Hamilton notes that Spenser refers to Ireland in his dedicatory sonnet to Ormond as the "saluage soyl" (Spenser 1977, 609) and it seems unavoidable that Spenser intends Ireland as "the saluage Iland" in Book 5 (5.11.39.3). Yet not all the 'savage' men in The Faerie Queene are barbaric. Book 6 presents the reader with two very different kinds of savage: the individual Saluage Man who shows compassion to Calepine and Serena and the collective Saluage Nation, who molest and attempt to eat Serena. Groups of 'savages' might also be docile and benevolent like the Saluage Nation who adore Una in Book 1. Although they are described as "A rude, misshapen, monstrous rablement" (1.6.8.7) they are astonished by Una's beauty and worship her for it. The other 'savage man' in The Faerie Queene is the monstrous figure of Lust who appears to be a fusion of the sexual promiscuity and degeneracy of the incestuous twins Argante and Ollyphant (3.7.37-52) combined with the appetite for human flesh shown by the Saluage Nation who accost Serena. Significantly, the origins of this "saluage man" are not known, but, like the children said by Irenius to have absorbed the nature of their Irish nurses via their breast milk (Spenser 1949, 119), he too has absorbed the nature of his feeders: "But whence he was, or of what wombe ybore, I Of beasts, or of the earth, I haue not red: / But certes was with milke of Wolues and Tygres fed" (4.7.7.7-9).

The gentler feelings of the 'civil' Saluage Man in Book 6 are inherent, not culturally acquired. He "neuer till this houre / Did taste of pittie, neither gentlesse knew" (6.4.3.1- 2) but is moved to compassion at Calepine's predicament and, like the shepherds in the Pastorella episode, treats his guests with appropriate courtesy. Spenser leaves the reader in no doubt as to the wild man's origins--"For certes he was borne of noble blood" (6.5.2.7)--and he emphasizes that despite a gruesome appearance noble blood will make itself apparent:

For howsoeuer it may grow mis-shapt, Like this wyld man, being vndisciplynd, That to all vertue it may seeme vnapt, Yet will it shew some sparkes of gentle mynd, And at the last breake forth in his owne proper kynd. (6.5.1.5-9)

Although Spenser is keen to underline the inherent nobility of the Saluage Man, which makes him behave with courtesy, he is also interested in his position outside civilization which demonstrates that nurture has failed nature. Unlike Pastorella, who has retained her innate 'superiority' to her surroundings, the Saluage Man is a hybrid, neither properly civilized nor completely savage.

The advocates of British colonialism attempted to draw up strict categories: Old English, Native or 'meere' Irish, and New English. That these distinctions could become blurred, as with the Old English, was a source of enormous anxiety. In '"Wildehirissheman': Colonialist Representation in Shakespeare's Henry V" David J. Baker refers to English anxieties about those who do not conform to the categories 
created by the colonialist: "The hybrid--either the degenerate Englishman or the incompletely assimilated Irishman--could become, for colonial power, a figure of threatening ambiguity ..." (Baker 1992, 40). As Hadfield and McVeagh point out in their study of British perceptions of Ireland, Hugh O'Neill was such as figure:

O'Neill troubled and enraged English writers not just because of the danger and disruption he caused, nor simply for the audacity of his nearly successful war, but because he was a transgressive and hybrid figure who in many ways resembled them. ... (Hadfield \& McVeagh 1994, 89)

Although Spenser's Saluage Man is an example of such ambiguity its threatening aspect has been contained by his inherent nobility despite the apparent assimilation evident in his appearance. The Old English should, like the Saluage Man, display a manner that sets them apart from the Native Irish but they do not. For Spenser, degeneration of the inherently noble, something to be feared, is entirely possible. The Saluage Man and, indeed, Pastorella may therefore be emblems of poetic wishfulfilment. If so, then the episodes featuring Pastorella and Serena give us an insight to the anxieties of the settler in the colonial project. Metaphors of sexual violence towards women convey the fear of miscegenation or contamination of the New English by the indigenous Irish.

\section{Flourdelis}

There are notable similarities among the Brigants who abduct Pastorella, the cannibals who assault Serena, and the mob sent by Grantorto to abduct Flourdelis (5.11.43-65). All are associated with Catholic lawlessness and disorder. Significant parallels can be drawn between the attack on Serena and the degradation of Flourdelis, Burbon's lady, which occurs toward the end of Book 5. Although the specific historical relevance of this allegory has been discussed by critics, its meaning in the sense of general Catholic rebellious violence, and particularly the depiction of Flourdelis as sexual transgressor, has been largely ignored. ${ }^{19}$ Yet it is significant that the rebellion of France is located in sexual terms and that a political agenda is evident in the fusion of the sexual and the territorial. It is no surprise that Flourdelis suffers aggression not only from the mob who abduct her but also from Artegall, the Protestant representative of English justice in Book 5.

Flourdelis is explicitly associated with France by her name which refers to the fleur-de-lis, the royal symbol of France. In Book 5 the woman-as-land trope is also evident in Irena (Ireland), whose liberation is the object of Artegall's quest, and Belge (the Low Countries). That France should also be included reveals Spenser's interest in vindicating the justice of Elizabeth's foreign policy. We have seen that, in their rhetoric about Ireland and the New World, Gernon and Raleigh used the woman-asland trope to construct the land as a virgin ripe for penetration. ${ }^{20}$

When Artegall comes across Burbon and the "rude rout" he is in the company of Sir Sergis. This is significant because prior to this we learn that Sergis has come from Irena (Ireland), to remind Artegall of his promise to "meete her at the saluage Ilands syde, / And then and there for triall of her right / With her vnrighteous enemy to fight" (5.11.39.3-5). Irena is an idealized personification of the land of Ireland, held in subjection to tyrannical Catholic power, but she also symbolizes Elizabeth as 
Virgin and rightful ruler of that land. Although Irena is constructed as an innocent victim of Catholic aggression, Flourdelis is blamed for her situation because she has been disloyal to her Protestant champion. Burbon explains her infidelity to Artegall and Sergis:

But sure to me her faith she first did plight, To be my loue, and take me for her Lord, Till that a Tyrant, which Grandtorto hight, With golden giftes and many a guilefull word Entyced her, to him for to accord.

O who may not with gifts and words be tempted?

Sith which she hath me euer since abhord, And to my foe hath guilefully consented:

Ay me, that euer guyle in wemen was inuented. $(5.11 .50 .1-9)$

Flourdelis has been seduced by the same tyrant who holds Irena against her will, the tyrant of course being Catholicism or a powerful symbol of it--either Philip of Spain or the Pope himself. Yet the circumstances of Flourdelis's betrayal are not clear.

Burbon says that "me she haue forlore" (5.11.49.7), which implies sexual infidelity, yet he qualifies this by saying "Whether withheld from me by wrongfull might, / Or with her owne good will, I cannot read aright" (5.11.49.8-9). It is clear, to the reader if not to Burbon, that Flourdelis does not want to give herself up to Grantorto entirely. Although Burbon claims that she has been seduced "With golden giftes and many a guilefull word" (5.11.50.4), she resists the force of Grantorto's mob (5.11.44.7-9), which implies that, although she has fallen, she is not beyond redemption.

Prefiguring the assault on Serena, Flourdelis's clothing is ripped by her keepers: "those villens through their vsage bad / Them fouly rent, and shamefully defaced had" (5.11.60.8-9). ${ }^{21}$ Torn clothes suggest that she has been sexually assaulted, which is consistent with her mood when she is rescued: "Her half dismayed they found in doubtfull plight, / As neither glad nor sorie for their sight" (6.11.60.4-5). ${ }^{22}$ When Burbon "with greedie great desyre" rushes at Flourdelis in an attempt to embrace her, she responds with disdain. For this reaction she is condemned by Artegall:

... What foule disgrace is this,

To so faire Ladie, as ye seeme in sight, To blot your beautie, that vnblemisht is, With so foule blame, as breach of faith once plight, Or change of loue for any worlds delight? Is ought on earth so pretious or deare, As prayse and honour? $(5.11 .62 .1-7)$

For Artegall, beauty is an outward manifestation of honour and, for a woman, honour is located in chastity. By being unfaithful, Flourdelis has ruined her beauty which before her infidelity was "vnblemisht". She is wholly blamed by Artegall for her predicament despite her earlier demonstration of resistance: 
Why then will ye, fond Dame, attempted bee

Vnto a strangers loue so lightly placed,

For guiftes of gold, or any worldly glee,

To leaue the loue, that ye before embraced,

And let your fame with falshood be defaced?

Fie on the pelfe, for which good name is sold,

And honour with indignitie debased:

Dearer is loue then life, and fame then gold;

But dearer then them both, your faith once plighted hold.

(5.11.63.1-9)

Like Munera (5.2.9), Flourdelis has accepted gifts of gold, symbolic of the Catholic church's ill-gotten wealth, and is subjected to Artegall's moralistic rant on the sins of worldly as opposed to spiritual riches. Artegall positions beauty as a signifier of Protestant faithfulness which has been tainted by association with the Roman Catholic Church. Artegall makes Flourdelis feel ashamed for her sexual treason:

Much was the Ladie in her gentle mind

Abasht at his rebuke, that bit her neare,

Ne ought to answere thereunto did find;

But hanging downe her head with heauie cheare,

Stood long amaz'd, as she amated weare.

$(5.11 .64 .1-5)^{23}$

Artegall's anger at Flourdelis's sexual infidelity indicates anxiety about Catholic power, which is here depicted as sexual aggression. A similar fear is evident in the encounters between Pastorella and the Captain and Serena and the cannibals.

Anxiety about power, possession, and the control of land is played out upon the body of a woman. The sympathy urged by the narrator when Pastorella is abducted by the Brigants is also elicited in the episode featuring Serena and the cannibals, although identification in the latter episode is somewhat problematized by emphasis on Serena as sexual Other in the poetic blazon. ${ }^{24}$ Because Flourdelis has been unfaithful the reader is distanced from her predicament. In this complex pattern of symbolism, woman as sexual Other may at times take precedence over woman as Protestant and/or New English victim.

In Books 5 and 6 of The Faerie Queene three female figures are attacked by 'Catholic' mobs: Flourdelis, Serena and Pastorella. Only the first of these has been assigned a national affiliation by critics. It has not been hitherto proposed that Pastorella and Serena may represent the New English colonialist in Ireland but the narrative subtext I have described suggests that the episodes in which they appear reveal New English fear of Native Irish attack. This is articulated through metaphors of miscegenation and the threat of sexual assault. Whilst both the Pastorella episode and the Serena episode dramatize the threat of penetration, it is only in the latter that we encounter the threat of total consumption. Here is both penetration and ingestion: the former suggests contamination, but the latter brings total annihilation. The Serena episode shows two ways the Irish might corrupt the New English: through sexual penetration which results in miscegenation, and through total loss of identity by annihilation. In Spenser's worst nightmare, the English are swallowed up by the Irish. 
Fitzpatrick, Joan. 1999a. "Pastoral Idylls and Lawless Rebels: Sexual Politics in Books 5 and 6 of Spenser's Faerie Queene." Explorations in Renaissance Culture. vol. 25. pp. 87-111.

\section{Notes}

${ }^{1}$ For publications on Spenser and Ireland since 1986 see Maley 1996a See also Hadfield 1997 and Maley 1997 both of which are influenced by post-colonial readings of the political situation in Early modern Ireland. Some of the most interesting work on Spenser and gender includes Davies 1986, 37-104; ; Shaver 1991; Berger Junior 1994; and Silberman 1995.

${ }^{2}$ In his book Spenser, Simon Shepherd divides his analysis of the View and The Faerie Queene under the chapter headings 'Politics' and 'Sex' respectively.

${ }^{3}$ By 'Other' I refer to Simone De Beauvoir's concept of the expression of a duality, that of the Self and the Other. This operates in the location of woman as 'the second sex', by which woman is positioned as the negative, the inessential, in contradistinction from the male. The notion of the Self and the Other is also expressed in group identification (for example nationalism and Protestantism) "no group ever sets itself up as the One without at once setting up the Other over against itself" (De Beauvoir 1953, 17).

${ }^{4}$ The term 'New English' describes the sixteenth and seventeenth-century English settlers in Ireland. 'Old English' is used to describe the descendants of the twelfthcentury Anglo-Norman settlers in Ireland and 'Native Irish' the indigenous Gaelic inhabitants of the island. There is disagreement between Nicholas Canny and Ciaran Brady as to whether the descendants of the twelfth-century Anglo-Norman settlers should be called 'Old English' or 'Anglo-Irish' (Canny \& Brady 1988, 203 n 9 and 212 $\mathrm{n} 5$ ). Canny prefers the former and Brady the latter but I think Canny is right to point out that the term 'Anglo-Irish' best defines those descended from the Elizabethan and Cromwellian conquests of Ireland.

${ }^{5}$ Although Williams is correct in his assertion that the word 'saluage' is used to describe a wood dweller who "partakes somewhat of the nature of the woods" he is wrong to claim that the word "has no connotation of ferocity or cruelty" (Williams 1967, 49). Throughout The Faerie Queene woodland is an unpredictable and hostile environment (like the Irish interior) and most of its inhabitants are aggressive, although there are exceptions: the Saluage Man in Book 6 and the Saluage Nation in Book 1.

${ }^{6}$ Hereafter referred to as 'the $\underline{V i e w}$ ', it was first attributed to Spenser by its first editor, James Ware, in 1633, thirty four years after the poet's death. Jean Brink, in an article published in 1994 has questioned the safety of attributing the View to Spenser because direct bibliographical evidence is lacking (Brink 1994, 203-28). Brink differs from Ciaran Brady in her assertion that Spenser wrote none of the three manuscripts that constitute A Brief Note of Ireland and promises to substantiate this in a forthcoming essay that has not yet appeared (Brink 1994, 227 n 40; Brady 1990, 111-12). If Spenser wrote the View and $\underline{A}$ Brief Note then the ideological, verbal, and thematic parallels that exist between these prose texts and The Faerie Queene show that they were a product of the same mind. If he did not write the $\underline{V i e w}$ and $\underline{A}$ Brief Note then the parallels show that these prose texts and The Faerie Queene were produced by a similar New English Protestant mind-set. Brady favours the latter hypothesis in his consideration of the second of the Brief Note manuscripts and 
claims that the third manuscript is the only one of the three that was written by Spenser (Brady 1990, 112). For a persuasive response to Brink's arguments, see Maley 1997, 163-94.

${ }^{7}$ All passages from Spenser's work, including the disputed View (see n 6, above), will be quoted from the Variorum Edition.

${ }^{8}$ Similarly, Gainsford announces that, although "The countrey is very fruitfull and pleasant, not so mountanous," it is "ill inhabited" (Gainsford 1618, 145).

${ }^{9}$ Willy Maley has recently drawn attention to the less obvious coupling of Spenser and Scotland which he claims has been overlooked in the attention given to Spenser's relationship with Ireland and the Irish (Maley 1996b).

${ }^{10}$ As outlined in the next section, 'Serena and the Saluage Nation', critics concur that the Saluage Nation conform to perceptions of the Irish as Savage Other. That the Brigants also represent Irish rebels was recognised by Tonkin when he stated that Serena is rescued "from a society whose behaviour closely parallels that of the Brigands" (Tonkin 1972, 144).

${ }^{11}$ Oram outlines Spenser's debts to Greek romance but acknowledges that "The motif of brigands living at the edge of civilized society . . . may owe something to Spenser's concern with the bands of Irish outlaw rebels mentioned in [the] Vewe ...." (Oram 1990, 112).

${ }^{12}$ Raids took place between rival Irish lords and upon the English Pale (Quinn \& Nicholls 1976, 33).

13 The Short Title Catalogue indicates that the woodcut illustrations designed to accompany Derricke's text can be found in only two copies of The Image of Ireland, one held by the National Library of Scotland in Edinburgh, and the other by Edinburgh University library (Pollard \& Redgrave 1986, 302). Although the collection of woodcuts attached to the Edinburgh University Library copy is incomplete it has the illustration of a cattle raid reproduced in Moody et al. 1976, plate 2.

${ }^{14}$ Hiram Morgan, who presents this previously unpublished text, claims that the 'Questions and Answars' was written in the first half of 1597 probably by Captain Nicholas Dawtrey (Morgan 1995, 81-82).

${ }^{15}$ Falkiner's transcription in full of Gernon's manuscript (Stowe ms. vol. 28, fol. 5) is the earliest printed edition of Gernon's Discourse.

${ }^{16} \mathrm{Gottfried}$ makes this claim in the variorum edition of the View: "[Irenius] must be associated with Irena, the name for Ireland in F.Q.. 5.1, since Irenius is an Englishman who has spent some time in Ireland" (Spenser 1949, 278).

${ }^{17}$ Critical analysis of Spenser's use of the blazon in Book 6 is usually restricted to the episode featuring Serena and the cannibals. For examples see McNeir 1969, 128; Fogarty 1989, 100-01; and Rowe 1989, 322-26. 
${ }^{18}$ This is the only printed version of Rich's manuscript.

${ }^{19}$ Heffner (1936, 324-35), Bennett (1942, 191), Jones (1930, 268), Phillips (1970, $117)$, Hamilton $(1977,609)$, and Prescott $(1990,121)$ have all recognised this episode as a thinly veiled historical allegory of Elizabeth's aid to Henri of Navarre, the first Bourbon King of France. Henri's succession to the throne had been challenged by the Catholic League supported by Philip of Spain. At one time a Huguenot (French Calvinist), Henri later renounced his Protestant faith and converted to Catholicism in order to rule France. See Spenser 1918, 303-5 and Greengrass 1995. Although an Irish Catholic connection was made by Heffner who claimed that the 'rude rout' that torments Flourdelis "is unmistakably such as Spenser saw in Ireland" he did not elaborate upon this suggestion (Spenser 1936, 260).

${ }^{20}$ For an early study of the woman-as-land trope with particular reference to America see. See also Patricia Parker's chapter on how this trope functions with regard to rhetoric, gender and property (Parker 1987, 126-54).

${ }^{21}$ The description of her sumptuous clothing--she is dressed in "roiall robes" with "many lewels dight" (5.11.60.7)--is reminiscent of the clothing of Duessa and thus the whore of Babylon. Duessa is given "gold and purple pall to weare", a "triple crowne", and "endowd with royall maiestye" by Orgoglio (1.7.16.3-5).

${ }^{22}$ Flourdelis's trauma may be compared with Serena's state of numb shock (6.8.5051 ) which was crudely characterized as unloving ingratitude by Hamilton (Spenser 1977, 680).

${ }^{23} \mathrm{Flourdelis's} \mathrm{shame} \mathrm{implies} \mathrm{that} \mathrm{her} \mathrm{transgression} \mathrm{has} \mathrm{been} \mathrm{a} \mathrm{sexual} \mathrm{one,} \mathrm{but} \mathrm{her}$ confusion also implies the shock consistent with a victim of sexual assault who is then subjected to a further verbal assault by Artegall.

${ }^{24}$ The blazon enacts a metaphorical dissection of a female figure but, as A. Leigh DeNeef notes, the cannibals take to a literal extreme the violent desires latent in the poetic mode because they want to literally dissect and consume Serena (DeNeef 1990, 637).

\section{Works Cited}

Baker, David J. 1992. "'Wildehirissheman": Colonialist Representation in Shakespeare's Henry V." English Literary Renaissance 22.1. 37-61.

Bennett, Josephine Waters. 1942. The Evolution of The Faerie Queene. New York. Burt Franklin.

Berger Junior, Harry. 1994. "Actaeon at the Hinder Gate: The Stag Party in Spenser's Gardens of Adonis." Desire in the Renaissance: Psychoanalysis and Literature. Edited by Valeria Finucci and Regina Schwartz. Princeton, NJ. Princeton University Press. 91-119. 
Borris, Kenneth. 1990. "Courtesy." The Spenser Encyclopedia. Edited by A. C. Hamilton. Toronto. University of Toronto. 194-95.

Brady, Ciaran. 1990. "A Brief Note of Ireland." The Spenser Encyclopedia. Edited by A. C. Hamilton. Toronto. University of Toronto Press. 111-12.

Brink, Jean R. 1994. "Constructing the View of the Present State of Ireland." Spenser Studies 11. 203-28.

Butlin, R. A. 1976. "Land and People, ‥ 1600." A New History of Ireland. 3. Edited by T. W. Moody, F. X. Martin and F. J. Byrne. Oxford. Oxford University Press. 14267.

Canny, Nicholas P. 1976. The Elizabethan Conquest of Ireland: A Pattern Established 1565-76. Hassocks. Harvester.

Canny, Nicholas and Ciaran Brady. 1988. "Debate: Spenser's Irish Crisis: Humanism and Experience in the 1590s." Past and Present.120. 201-15.

Carroll, Clare. 1990. "The Construction of Gender and the Cultural and Political Other in The Faerie Queene 5 and A View of the Present State of Ireland: the Critics, the Context, and the Case of Radigund." Criticism 32.2. 163-92.

Cavanagh, Sheila T. 1994. Wanton Eyes and Chaste Desires: Female Sexuality in The Faerie Queene. Bloomington. Indiana University Press.

Chang, H. C. 1955. Allegory and Courtesy in Spenser: A Chinese View. Edinburgh. Edinburgh University Press.

Davies, Stevie. 1986. The Idea of Woman in Renaissance Literature: The Feminine Reclaimed. Brighton, Sussex. Harvester Press.

De Beauvoir, Simone. 1953. The Second Sex. Trans. and ed. H. M. Parshley. London. Jonathan Cape.

DeNeef, A. Leigh. 1990. "Serena." The Spenser Encyclopedia. Edited by A. C. Hamlton. Toronto. University of Toronto Press. 733.

Falkiner, C. Litton. 1904. Illustrations of Irish History and Topography, Mainly of the Seventeenth Century. London. Longmans.

Fogarty, Anne. 1989. "The Colonization of Language: Narrative Structures in A View of the Present State of Ireland and The Faerie Queene, Book VI." Spenser and Ireland: An Interdisciplinary Perspective. Edited by Patricia Coughlan. Cork. Cork University Press. 75-108.

Friel, Brian. 1989. Making History. London. Faber and Faber. 
Gainsford, Thomas. 1618. The Glory of England, or a True Description of Blessings, Whereby She Triumpheth Over All Nations. STC 11517.. London. E. Griffin for T. Norton.

Gray, M. M. 1930. "The Influence of Spenser's Irish Experiences on The Faerie Queene." Review of English Studies 6.21-24. 413-28.

Greengrass, Mark. 1995. France in the Age of Henri IV: the Struggle for Stability. London. Longman.

Hadfield, Andrew and John McVeagh, eds. 1994. Strangers to That Land: British Perceptions of Ireland from the Reformation to the Famine. Ulster Editions and Monographs. 5. Gerrards Cross, UK. Colin Smythe.

Hadfield, Andrew. 1997. Edmund Spenser's Irish Experience: Wilde Fruit and Salvage Soyl. Oxford. Clarendon Press.

Hinton, Edward M. 1940. "Rych's Anothomy of Ireland, with an Account of the Author." Publications of the Modern Language Association of America 55. 73-101.

Jones, H. S. V. 1930. A Spenser Handbook. New York. Appleton-Century-Crofts.

Maley, Willy. 1996a. "Spenser and Ireland: An Annotated Bibliography, 1986-96." Irish University Review 26.2. 342-53.

Maley, Willy. 1996b. "Spenser and Scotland: The View and the Limits of Anglo-Irish Identity." Prose Studies 19.1. 1-18.

Maley, Willy. 1997. Salvaging Spenser. Basingstoke. Macmillan.

McCracken, Eileen. 1959. "The Woodlands of Ireland Circa 1600." Irish Historical Studies 11.44. 271-96.

McNeir, Waldo F. 1969. "The Sacrifice of Serena: The Faerie Queene VI.viii.31-51." Festschrift Fur Edgar Mertner. Edited by Bernhard Fabian and Ulrich Suerbaum. Munich. Wilhelm Fink. 117-56.

Montrose, Louis Adrian. 1983. "Of Gentlemen and Shepherds: The Politics of Elizabethan Pastoral Form." English Literary History 50.3. 415-59.

Moody, T. W., F. X. Martin and F. J. Byrne, eds. 1976. A New History of Ireland. Vol. 3. 9 vols. Oxford. Oxford University Press.

Morgan, Hiram. 1995. "A Booke of Questions and Answars Concerning the Warrs or Rebellions of the Kingdome of Irelande." Analecta Hibernica 36. 79-132.

Moryson, Fynes. 1617. An Itinerary Written By Fynes Moryson Gent. (Containing His Ten Yeeres Travell Through the Twelve Dominions of Germany, Bohmerland, . . . France, England, Scotland, and Ireland). STC 18205. London. J. Beale. 
Moryson, Fynes. 1903. Shakespeare's Europe: Unpublished Chapters of Fynes Moryson's Itinerary, Being a Survey of the Condition of Europe at the End of the 16th Century. Ed. Charles Hughes. London. Sherratt \& Hughes.

Oram, William A. 1990. "Brigands." The Spenser Encyclopedia. Edited by A. C. Hamilton. Toronto. University of Toronto Press. 112-13.

Parker, Patricia. 1987. Literary Fat Ladies: Rhetoric, Gender, Property. London. Methuen.

Phillips, James E. 1970. "Renaissance Concepts of Justice and the Structure of The Faerie Queene, Book V." Huntington Library Quarterly 33.2. 103-20.

Pollard, A. W. and G. R. Redgrave. 1986. A Short-title Catalogue of Books Printed in England, Scotland, \& Ireland and of English Books Printed Abroad 1475-1640. Vol. 1: A-H. 3 vols. London. The Bibliographical Society.

Prescott, Anne Lake. 1990. "Burbon." The Spenser Encyclopedia. Edited by A. C. Hamlton. Toronto. University of Toronto Press. 121.

Quinn, D. B. and K. W. Nicholls. 1976. "Ireland in 1534." A New History of Ireland. 3. Edited by T. W. Moody, F. X. Martin and F. J. Byrne. Oxford. Oxford University Press. 1-38.

Raleigh, Walter. 1596. The Discouerie of the Large, Rich, and Bewtiful Empire of Guiana. Performed in the Yeare 1595. By Sir W. Ralegh. London. R. Robinson.

Rowe, George E. 1989. "Privacy, Vision, and Gender in Spenser's Legend of Courtesy." Modern Language Quarterly 50. 309-36.

Shaver, Anne. 1991. "Rereading Mirabella." Spenser Studies 9. 211-26.

Shepherd, Simon. 1989. Spenser. Atlantic Highlands, NJ. Humanities Press International.

Silberman, Lauren. 1995. Transforming Desire: Erotic Knowledge in Books III and IV of The Faerie Queene. Berkeley. University of California Press.

Spenser, Edmund. 1918. The Faerie Queene Book V. Ed. Alfred B. Gough. Oxford. Clarendon Press.

Spenser, Edmund. 1936. The Faerie Queene: Book Five. Ed. Ray Heffner. The Works of Edmund Spenser: A Variorum Edition. 5. Baltimore. Johns Hopkins.

Spenser, Edmund. 1949. Prose Works. Ed. Rudolf Gottfried. The Works of Edmund Spenser: A Variorum Edition. 10. Baltimore. Johns Hopkins.

Spenser, Edmund. 1977. The Faerie Queene. Ed. A. C. Hamilton. Annotated English Poets. London. Longman. 
Staton, Walter F. 1966. "Italian Pastorals and the Conclusion of the Serena Story." Studies in English Literature: 1500-1900 6.1. 35-42.

Tayler, Edward William. 1964. Nature and Art in Renaissance Literature. New York. Columbia University Press.

Tonkin, Humphrey. 1972. Spenser's Courteous Pastoral: Book Six of the Faerie Queene. Oxford. Clarendon.

Williams, Arnold. 1967. Flower on a Lowly Stalk: The Sixth Book of the Faerie Queene. Michigan. Michigan State University Press. 